S1-06

ペプチド輸送体を介する $\beta$-ラクタム系抗生物質輸送の 分子・細胞生物学的解析

○齋藤秀之、寺田智祐、向井真由美、奥田真弘、乾 賢一 京大·医・病院薬戍部

\title{
MOLECULAR AND CELLULAR BIOLOGY OF $\beta$-LACTAM ANTIBIOTIC TRANSPORT VIA PEPTIDE TRANSPORTER
}

Hideyuki SAITO, Tomohiro TERADA, Mayumi MUKAI, Masahiro OKUDA, and Ken-ichi INUI

Department of Pharmacy, Kyoto University Hospital

【目的】小腸並びに腎尿細管の上皮細胞には、2〜3個のアミノ酸からなるオリゴペプチド を能動的に輸送する $\mathrm{H}^{+}$駆動型ペプチド輸送体が発現しており、タンパク質の吸収・恒常性 維持に重要な役割を担っている。ペプチド輸送体は広範な基質認識能を有するため、 $\beta$-ラ クタム系抗生物質やbestatin等のペプチド類似薬物を誤認識し輸送することが、膜小胞系や 培養細胞系を用いた薬物輸送研究によって解明されてきた(1-4)。一方、荷電状態が異なっ たり多様な側鎖を持つ $\beta$-ラクタム系抗生物質が、同一のペプチド輸送体によって認識され 得るのか、あるいは輸送体が複数種存在し、それぞれの基質認識性に合致した薬物の輸送 を媒介しているのか不明の点も多い。さらに、腎特異的なペプチド輸送体の存在も示唆さ れていることから、ペプチド様薬物の吸収・排泄といった動態制御過程に多様なペプチド 輸送体群の関与している可能性が推察される。本研究では、ペプチド輸送体を介する薬物 輸送の分子機構論的解析を目的とし、ラットに発現しているペプチド輸送体のcDNAクロー ニングと、それに基づく構造解明、臓器分布並びに $\beta$-ラクタム系抗生物質の認識特性につ いて検討を加えた。

【方法】 Reverse Transcription-Polymerase Chain Reaction (RT-PCR)及びcDNAライブラリーの スクリーニング: ウサギ小腸オリゴペプチド輸送体PEPT1(5)のアミノ酸配列を基に degenerate primerを合成し、ラット組織mRNAを用いてRT-PCRを行った。ウサギPEPT1と相

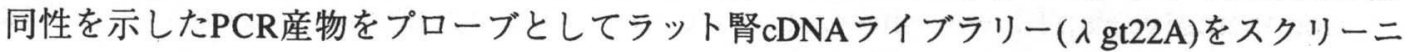
ングし、最終的にラットPEPT1及びPEPT2 cDNAを単離した。各々の塩基配列は、pSPORT1 にサブクローニングした後、合成primer及びSequenase ${ }^{\mathrm{TM}}$ を用いて決定した。 in vitroトラン スレーション: ウサギ網状赤血球ライセートを用いて、ラットPEPT1 cRNAの ${ }^{35}$ S-methionine 標識翻訳産物を電気泳動で分離後検出した。ノーザンブロット分析: ラットの各組織由来 mRNAをホルムアルデヒド含有アガロースゲルで分離後、ナイロンメンブランにブロッテ イングし、32 P標識PEPT cDNAを用いてハイブリダイゼーションを行った。ウェスタンブロ ット分析: ラットPEPT1のC末端部合成ペプチドに対するウサギ抗血清並びにHRP標識二次 抗体を用い、小腸及び腎皮質刷子縁膜に局在するPEPT1の免疫学的検出を行った。アフリ カツメガエル卵母細胞翻訳系による輸送機能発現: ラットPEPT cDNAを鋳型として合成した cRNAを卵母細胞に注入後 $19^{\circ} \mathrm{C}$ で一定期間培養し、 $\beta$-ラクタム系抗生物質の取り込み活性を 測定した。薬物の定量は除タンパク・抽出後、HPLCによって行った。 
【結果・考察】ラットPEPT1の構造、臓器分布及び輸送機能(6): CDNAライブラリーより単 離したラットPEPT1 cDNAは全長2,929 bpであり、open reading frameには710個のアミノ酸か らなる12回膜貫通型タンパク質がコードされていた。ラットPEPT1とウサギ及びヒト PEPT1(7)との相同性を比較したところ、一致するアミノ酸はそれぞれ77\%及び83\%であった が、9番目と10番目の膜貫通 $\alpha$-ヘリックス間に存在する細胞外ループの相同性はいずれも低 いことがわかった(Fig. 1)。

\begin{tabular}{|c|c|c|}
\hline & & \\
\hline ratPEPT1 & 1 & MGMSKSRGCFGYPLSIFFIVVNEFCERFSYYGMRALLVLYFRNFLGWDDDLSTAIYHTFV \\
\hline rabbitPEPT1 & & $\ldots \ldots$ LS $\ldots \ldots \ldots \ldots \ldots \ldots \ldots \ldots \ldots$. $\ldots \ldots \ldots$ I. . . . . . V . . . . \\
\hline humanPEPT1 & & $\ldots \ldots$ HSF . . . . . . . . . . . . . . . . . . . . \\
\hline ratPEPT 1 & 61 & 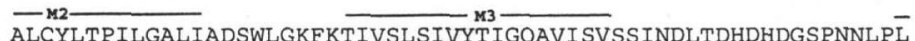 \\
\hline rabbitPEPT1 & 01 & ALCYLIFILGALIADSWLGKFKTIVSLSIVYIIGQAVISVSSINDLIDHDHDGSFINLFL \\
\hline humanPEPT1 & & . \\
\hline & & $-\mathrm{m} 4 \longrightarrow$ \\
\hline ratPEPT1 & 121 & HVALSMIGLALIALGTGGIKPCVSAFGGDQFEEGQEKQRNRFFSIFYLAINAGSLLSTII \\
\hline rabbitPEPT1 & & 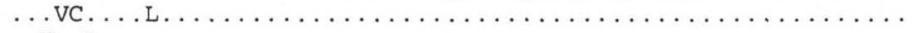 \\
\hline humanPEPT1 & & 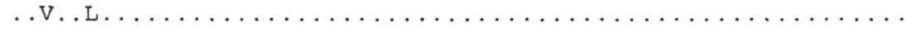 \\
\hline & & - \\
\hline ratPEPT1 & 181 & TPILRVQQCGIHSQQACYPLAFGVPAALMAVALIVFVLGSGMYKKFQPQGT SSGKVAKCI \\
\hline rabbitPEPT1 & & $\ldots$ MV . . . . . . VK . . . . . . . I. . . . . . . . II . . . . . K. . NILS . V. . \\
\hline humanPEPT1 & & $\ldots$ M. . . . . . . . . . . . . . . . . . \\
\hline ratPEPT1 & 241 & GFAIKNRFRHRSKAFPKREHWLDWAKEKYDERLISQIKMVTKVMFLYIPLPMFWALFDQQ \\
\hline rabbitPEPT1 & & 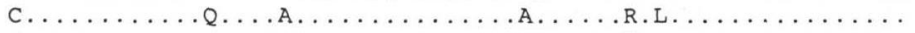 \\
\hline humanPEPT1 & & 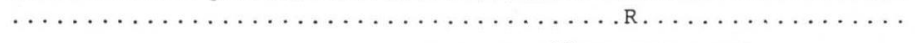 \\
\hline EPT1 & 301 & GSRWTLQATTMTGKIGTIEIOPDOMOTVNAILIVIMVPIVDAVVYPLIAKCGFNFTSLKK \\
\hline rabbitPEPT1 & & 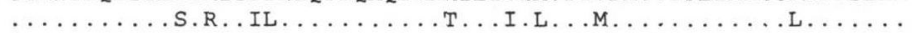 \\
\hline humanPEPT1 & & 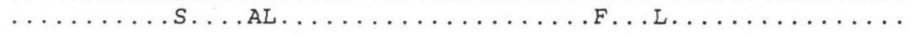 \\
\hline & & - M9 —__ \\
\hline ratPEPT1 & 361 & MTVGMFLASMAFVVAAIVQVEIDKTLPVFPSGNQVQIKVLNIGNNDMAVYFPGKNVTVAQ \\
\hline rabbitPEPT1 & & .I. . . . . . . . . . . . . . KA.E. . . . V.SEN. IISL .QT . LN. \\
\hline humanPEPT1 & & 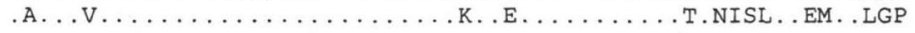 \\
\hline T1 & 421 & MSQTDTFMTFDVDQLTSINVSSPGSPGVTTVAHEFEPGHRHTLLVWGPNLYRVVKDGLNQ \\
\hline rabbitPEPT1 & & 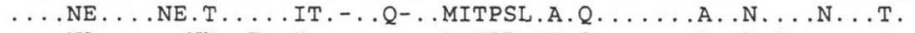 \\
\hline EPT 1 & & 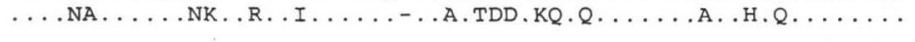 \\
\hline & 481 & KPEKGENGIRFVSTLNEMITI KMSGKVYENVTSH \\
\hline rabbitPEPT1 & & .SD . . . . . N. YSQP.NVT . . . . HIA.YN. E. . T. . V.GF.VSSAG. SEQ. \\
\hline humanPEPT1 & & 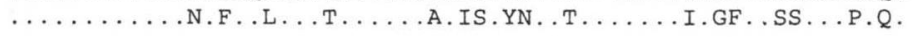 \\
\hline ratPEPT1 & 541 & SSDFKSSNLDFGSAYTYVIRSRASDGCLEVKEFEDIPPNTVNMALQI PQYFLLTCGEVVF \\
\hline rabbitPEPT1 & & 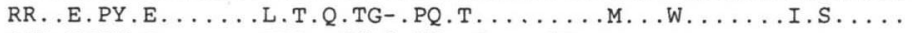 \\
\hline humanPEPT1 & & 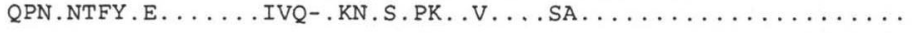 \\
\hline ratPE & 601 & $\overline{\text { SVTGLEFSYSQAPSNMKSVLQAGWLLTVAIGNIIVLIVAEAGHFDKQWAEYVLFASLLLV }}$ \\
\hline rabbitPEPT1 & &.$I \ldots \ldots \ldots \ldots \ldots \ldots \ldots$. . . . . . . . . . . . . . . . . \\
\hline humanPEPT1 & & 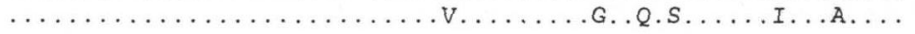 \\
\hline ratPEPT1 & 661 & VCIIFAIMARFYTYINPAEIEAQFDEDEKKKGVGKENPYSSLEPVSQTNM 710 \\
\hline rabbitPEPT1 & & 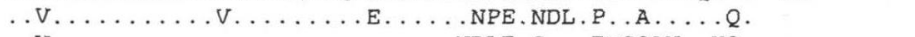 \\
\hline humanPEPT1 & & $\ldots$ V. . . . . . . . . . . . . . . NRLE . S . FMGAN. KQ \\
\hline
\end{tabular}

Fig. 1. ラット、ウサギ並びにヒトPEPT1のアミノ酸配列の相同性.・はラットPEPT1と一 致するアミノ酸を示す. アミノ酸配列上の実線(M1 - M12)は推定細胞膜貫通領域.

ラットPEPT1 cDNAを鋳型として合成したRNAを用いてin vitroトランスレーションを行った 結果、ラットPEPT1は分子量約 $75 \mathrm{kDa}$ の糖タンパク質であることが示された。ノーザンブロ ット分析並びにRT-PCRによってPEPT1の臓器分布を調べた結果、PEPT1 mRNAの発現は小 腸に最も多く、腎皮質でも若干認められた。そこで小腸及び腎皮質の刷子縁膜を分離精製 
し、PEPT1に対する抗体を用いて ウェスタンブロッティングを行っ たところ、いずれの組織において も分子量75 kDaのバンドが検出さ れた(Fig. 2)。また免疫染色によ って、ラットPEPT1のCRNAを注 入した卵母細胞膜上にPEPT1タン パク質の発現していることが確認 された。ラットPEPT1 cRNA注入 卵母細胞では、 $\mathrm{H}^{+}$勾配存在下で ceftibuten及びcephradineの取り込み が顕著に増大した。またこれら薬 物の取り込み活性は、過剩量のジ ペプチド共存によって阻害された。 ラットPEPT1発現卵母細胞を用い て、ceftibuten及びcephradine取り込 みの濃度依存性を測定し輸送パラ メー夕を求めた結果、

見かけの Km值はそ れぞれ0.9 mM及び 12 mMであった(Fig. 3)。従って、 ceftibutenはラット PEPT1に対して cephradineよりも約 14 倍高い親和性を有す ることがわかった。

\section{ラットPEPT2の構} 造及び藏器分布(8): ラ ットPEPT2 cDNAは 全長3,938 bpであり、 729個のアミノ酸か

\section{Small intestine Kidney cortex}

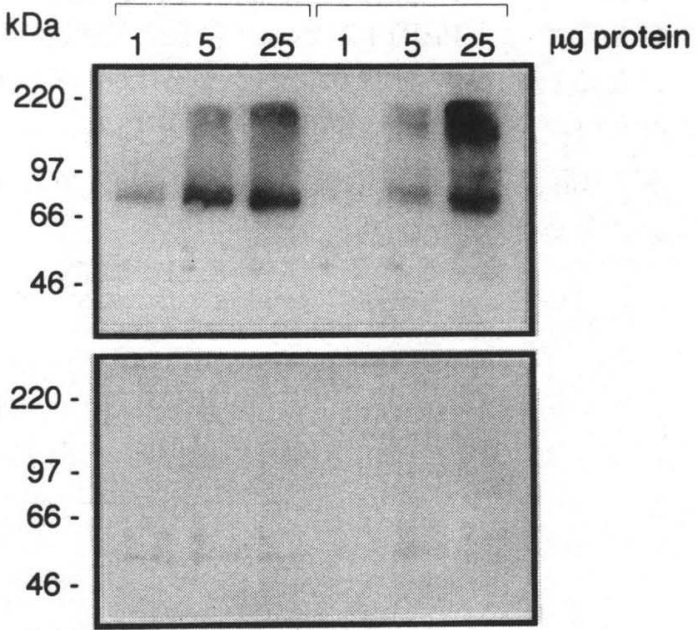

Fig. 2. ウェスタンブロッティングによるラット小腸 及び腎尿細管刷子縁膜におけるPEPT1の検出.

らなる12回膜貫通型タンパク質をコードする open reading frameを有していた。ラットPEPT2 とPEPT1間の相同性は48\%であり、特に推定膜貫通領域では高いアミノ酸保存性が見られた (Fig. 4)。ラットPEPT2とヒトPEPT2(9)との相同性は82\%であった。ノーザンブロット分析の 結果、ラットPEPT2 mRNAは腎髄質に最も強く発現しており、脳及び肺でも検出されたが、 小腸では認められなかった。

以上の結果から、ラットPEPT1は小腸並びに腎皮質の刷子縁膜に発現している分子量約 $75 \mathrm{kDa}$ の12回膜貫通型タンパク質であること、アニオン型ceftibuten及び両性イオン型 cephradineを基質として認識し、 $\mathrm{H}^{+}$勾配依存的に輸送することが明らかとなった。またラッ 
トPEPT2は、PEPT1と共通の ペプチド輸送体ファミリーに 属する12回膜貫通型タンパク 質であること、PEPT2 mRNA の臓器分布はPEPT1の場合と は異なり、腎にほぼ特異的に 発現していることがわかった。 今後さらに、PEPT1とPEPT2 の薬物認識、臓器分布、細胞 膜局在性及び種差等の分子的 解析を基盤とし、 $\beta$-ラクタム 系抗生物質を含むぺプチド類 似薬物の吸収・分泌制御にお けるペプチド輸送体群の薬物 動態学的寄与を解明すること によって、得られた情報を輸 送体-薬物間相互作用の構造活 性相関や製剂設計に還元し得 るものと考える。

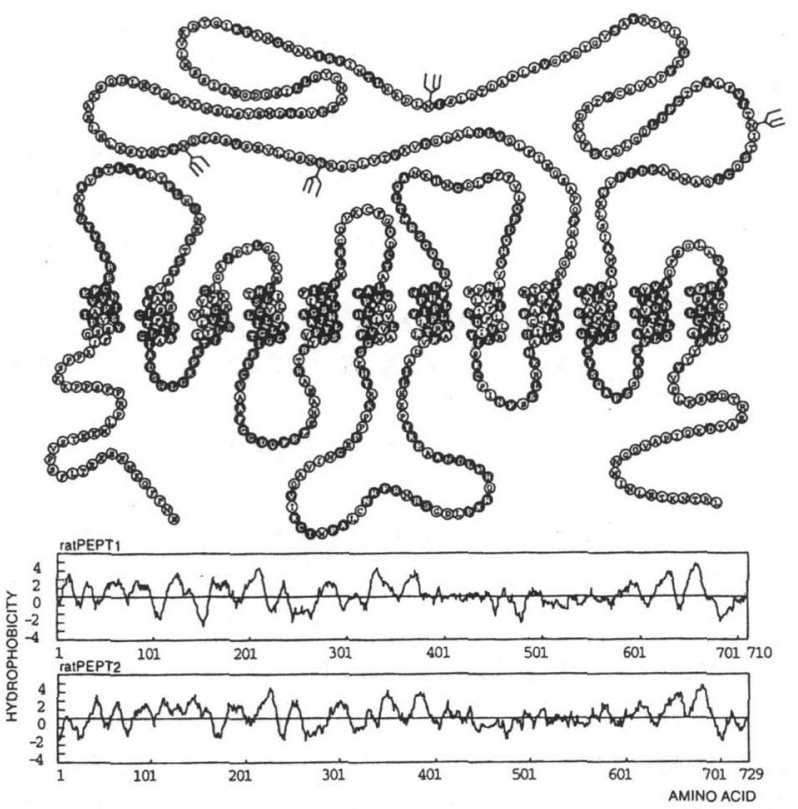

Fig. 4. ラットPEPT2の推定二次構造. ・はラットPEPT1 と一致するアミノ酸、○は異なるアミノ酸を示す. 下図は両輸送体の疎水性プロット.

ABSTRACT A complementary DNA (cDNA) encoding the rat $\mathrm{H}^{+}$-coupled peptide transporter, designated PEPT1, was isolated, and the transport characteristics of orally active $\beta$-lactam antibiotics were assessed by measuring uptake into Xenopus oocytes expressing the rat PEPT1. The rat PEPT1 cDNA encoded a 710-amino acid protein with $77 \%$ and $83 \%$ identity to the rabbit PEPT1 and human PEPT1, respectively. The message for rat PEPT1 was 2.9 kilobases and was found predominantly in the small intestine, whereas reverse transcription-polymerase chain reaction amplification revealed that the message was expressed both in the small intestine and in the kidney cortex. The 75-kDa protein was identified by translation of in vitro synthesized transcript of rat PEPT1 cDNA using rabbit reticulocyte lysates and by Western blot analysis using a specific antibody against the rat PEPT1. When expressed in oocytes, rat PEPT1 stimulated the uptake of ceftibuten (anion) and cephradine (zwitterion) in the presence of an inward $\mathrm{H}^{+}$gradient, and the expressed upake was inhibited by excess dipeptides. Kinetical analysis revealed that ceftibuten has 14-fold higher affinity for the rat PEPT1 than cephradine. Thus, the rat PEPT1 mediates $\mathrm{H}^{+}$-coupled uphill transport of the oral $\beta$-lactam antibiotics across the brush-border membranes of intestinal and renal proximal tubular cells. We also isolated a cDNA encoding another member of peptide transporter family, rat PEPT2. The rat PEPT2 consists of 729 amino acids with $48 \%$ amino acid identity to the rat PEPT1. In contrast to the rat PEPT1, mRNA expression of rat PEPT2 was predominant in the kidney medulla, and was also detected in the brain and lung tissues, but not in the small intestine. These peptide transporters should be responsible for intestinal absorption and/or for renal handling of peptide-like drugs such as $\beta$-lactam antibiotics.

REFERENCES (1) K. Inui et al., Biochim. Biophys. Acta, 769, 449 (1984) (2) T. Okano et al., J. Biol. Chem., 261, 14130 (1986) (3) A. Tsuji et al., J. Pharmacol. Exp. Ther., 241, 594 (1987) (4) H. Saito and K. Inui, Am. J. Physiol., 265, G289 (1993) (5) Y.-J. Fei et al., Nature, $\underline{368} 563$ (1994) (6) H. Saito et al., submitted. (7) R. Liang et al., J. Biol. Chem., 270, 6456 (1995) (8) H. Saito et al., submitted. (9) W. Liu et al., Biochim. Biophys. Acta, 1235, 461 (1995) 